\title{
Severe mortality in wild Atlantic salmon Salmo salar due to proliferative kidney disease (PKD) caused by Tetracapsuloides bryosalmonae (Myxozoa)
}

\author{
Erik Sterud ${ }^{1,6}$, Torbjørn Forseth ${ }^{2}$, Ola Ugedal ${ }^{2}$, Trygve T. Poppe ${ }^{3}$, \\ Anders Jørgensen ${ }^{1}$, Torkjell Bruheim ${ }^{4}$, Hans-Petter Fjeldstad ${ }^{5}$, Tor Atle Mo $^{1, *}$ \\ ${ }^{1}$ National Veterinary Institute, PO Box 8156 Dep. 0033 Oslo, Norway \\ ${ }^{2}$ Norwegian Institute for Nature Research, 7485 Trondheim, Norway \\ ${ }^{3}$ Norwegian School of Veterinary Science, PO Box 8146 Dep. 0033 Oslo, Norway \\ ${ }^{4}$ National Veterinary Institute, 7485 Trondheim, Norway \\ ${ }^{5}$ Sintef, 7465 Trondheim, Norway \\ ${ }^{6}$ Present address: Standards Norway, PO Box 242, 1326 Lysaker, Norway
}

\begin{abstract}
Extensive mortality in Atlantic salmon fry was reported in the River Åelva from 2002 to 2004. Dead fish were collected in late summer 2006, and live fish were sampled by electrofishing in September the same year. At autopsy and in histological sections, the fish kidneys were found to be pale and considerably enlarged. Proliferative lesions with characteristic PKX cells were seen in a majority of the fish. DNA from kidney samples of diseased fish was subjected to PCR and sequencing, and the amplified sequences matched those of Tetracapsuloides bryosalmonae. We concluded that this myxozoan transmitted from bryozoans was the main cause of the observed mortality in salmon fry in 2006. Results from quantitative electrofishing in 2005 and 2006, combined with the observed fry mortality from 2002 to 2004, show that the smolt production in the river is severely reduced and that $T$. bryosalmonae is the most likely explanation for this decline. The present study is the first to report a considerable negative population effect in wild Atlantic salmon due to proliferative kidney disease (PKD). It also represents the northernmost PKD outbreak in wild fish. The river is regulated for hydroelectric power purposes, causing reduced water flow and elevated summer temperatures, and the present PKD outbreak may serve as an example of increased disease vulnerability of northern fish populations in a warmer climate.
\end{abstract}

KEY WORDS: Myxozoa - Proliferative kidney disease $\cdot$ PKD - Tetracapsuloides bryosalmonae . Malacosporea $\cdot$ Salmonid

\section{INTRODUCTION}

Considerable mortality among 0+ Atlantic salmon Salmo salar L. was seen in the River Åelva, Central Norway, in 2002, 2003, and 2004 (E. Sylten pers. comm.). This river is regulated for hydroelectric power purposes, and management authorities suggested that oxygen deficiency during periods with low water discharge and high temperatures was the rea- son for the observed mortality. Thus, temperature and oxygen concentrations were monitored throughout the summers of 2005 and 2006. No mortality was reported in 2005, but in 2006 fish mortality was once again seen during a period when oxygen monitoring showed far from lethal levels (8 to $9 \mathrm{mg} \mathrm{O}_{2} \mathrm{l}^{-1}$ ), suggesting that the observed mortality was caused by disease. At autopsy, dead fish collected in the river were found to have pale and enlarged kidneys. Prolif- 
erative kidney disease (PKD) was suspected as a possible diagnosis.

PKD has been regularly diagnosed in Atlantic salmon, brown trout Salmo trutta L. and rainbow trout Oncorhynchus mykiss (Walbaum) in freshwater fish farms in southern Norway since 1972. PKD was also diagnosed in wild Atlantic salmon parr in the River Håelva in 1989 (T. Håstein pers. comm.). These diagnoses were based on clinical history, gross lesions, and characteristic histopathological findings with PKX cells.

Water temperatures above $12^{\circ} \mathrm{C}$ may induce clinical PKD (Morris et al. 2005), but normally, clinical PKD outbreaks occur at water temperatures above $15^{\circ} \mathrm{C}$ (Tops et al. 2006). In Norwegian fish farms, outbreaks typically occur between August and October ( $\mathrm{T}$. Håstein pers. comm.). In Switzerland, several populations of brown trout are declining. This decline was linked to an increasing occurrence of PKD, which in turn was connected to higher temperatures in several Swiss rivers (Wahli et al. 2002). An increase in prevalence and severity of PKD in northerly regions as a direct consequence of temperature increase due to climate changes has been predicted (Tops et al. 2006).

Tetracapsuloides bryosalmonae (Canning, Curry, Feist, Longshaw and Okamura, 1999) is the causative agent of PKD in salmonids (Canning et al. 1999). It belongs to the class Malacosporea in the phylum Myxozoa and is a parasite of freshwater bryozoans and fish (Canning et al. 2000, 2002). Fish hosts include Atlantic salmon, brown trout, rainbow trout, Arctic charr Salvelinus alpinus (L.), brook trout $S$. fontinalis (Mitchill) grayling Thymallus thymallus (L.), and the nonsalmonid pike Esox lucius L. (Feist et al. 2002). Brook trout does not seem to develop PKD (Feist et al. 2002). T. bryosalmonae spores can be transmitted from fish to the freshwater bryozoan Fredericella sultana and back to fish (Morris \& Adams 2006). These findings indicate that fish are an integral part of this parasite's life-cycle. This should have important implications for enhancement programs involving stocking of fish.

Bryozoan hosts for Tetracapsuloides bryosalmonae include Cristatella mucedo, Plumatella rugosa, Pectinatella magnifica, Fredericella sultana, and an unidentified Plumatella sp. (Gay et al. 2001). The distribution and ecology of bryozoans in Norway has been extensively studied and only 2 of these known hosts have been found, i.e. C. mucedo and F. sultana, both with a nation-wide distribution (K. A. Økland \& J. Økland 2000, 2001, J. Økland \& K. A. Økland
2005). The presence of malacosporeans in bryozoans in Norway has never been studied.

In the present study, we describe the occurrence of PKD and Tetracapsuloides bryosalmonae in juvenile Atlantic salmon from the River Åelva in Central Norway. To the best of our knowledge, this is the northernmost registration of PKD so far. The observed reduction in recruitment of salmon in the River Åelva in recent years is evaluated in light of the present observations.

\section{MATERIALS AND METHODS}

Study river. River Åelva is part of the Åbjøra watercourse in Central Norway ( $\left.65^{\circ} 4^{\prime} \mathrm{N}, 12^{\circ} 26^{\prime} \mathrm{E}\right)$ (Fig. 1). Its natural total catchment area is $519 \mathrm{~km}^{2}$. The watercourse is regulated for hydroelectric power purposes, and $26 \%\left(134.6 \mathrm{~km}^{2}\right)$ of the upper part of the catchment area was drained to a neighbouring watercourse in 1979. Another $3.6 \mathrm{~km}^{2}$ was diverted in 2001. Consequently, the annual average water discharge into the River Åelva has been reduced, from $30.3 \mathrm{~m}^{3} \mathrm{~s}^{-1}$ before 1979 to $18.5 \mathrm{~m}^{3} \mathrm{~s}^{-1}$ after 2001 . The river system holds populations of anadromous Atlantic salmon, brown trout and Arctic charr. These ascend the River Åelva $(20 \mathrm{~km})$, migrate through Lake Åbjørvatn $\left(4.8 \mathrm{~km}^{2}\right.$ surface area) and continue $7.5 \mathrm{~km}$ farther up the River Åbjøra (Fig. 1). Resident populations of brown trout and Arctic charr are also found in Lake Åbjørvatn. In this study, we focus on the situation in the River Åelva.

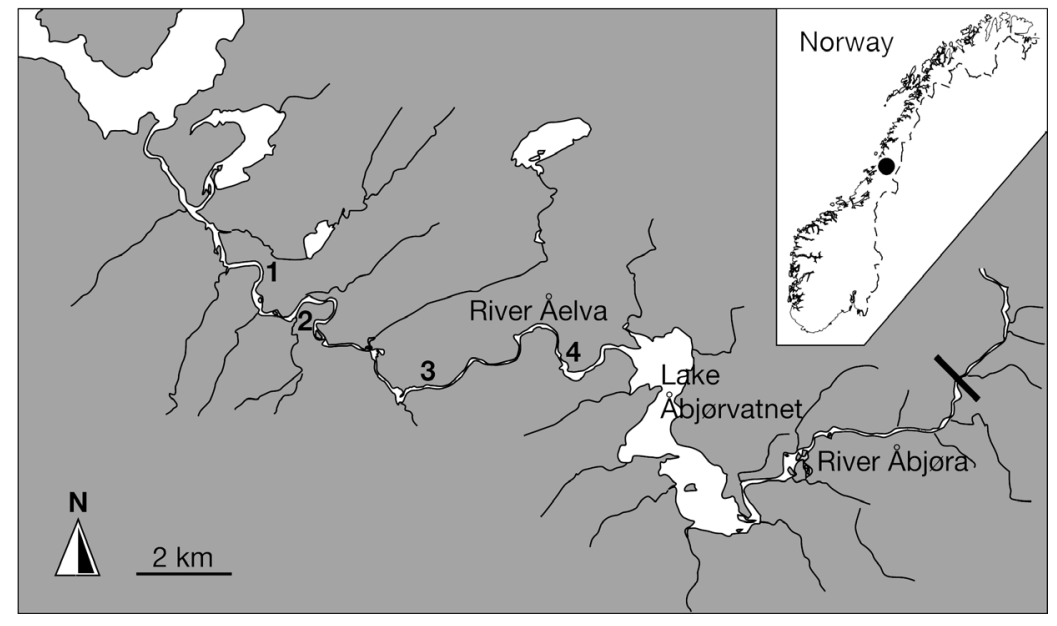

Fig. 1. The study area (Åbjøra watercourse) in Central Norway. Sampling was performed in the River Åelva, but anadromous salmonids can ascend $7.5 \mathrm{~km}$ of the River Åbjøra (upper migration barrier is indicated by bold line). (1) logging station for historical temperature data $(1974,1976-77)$; (2) logging station for oxygen and temperature data in 2005 and 2006, observation area for dead fish, and lower electrofishing area for PKD diagnosis; (3) middle electrofishing area; and (4) upper electrofishing area 
Fish sampling. Dead juvenile Atlantic salmon were collected by a local landowner from June to September 2006, preserved by freezing or in formaldehyde, and transported to the National Veterinary Institute of Norway. Non-systematic registrations of dead fish from 2002 and 2003, and a systematic registration from 2004 were also available (E. Sylten pers. comm.). In 2004, an area of approximately $500 \mathrm{~m}^{2}$ (Fig. 1) was visited nearly every day from 27 July to 8 October. The number of dead fish was registered, some of the fish were sampled, and on most occasions the water temperatures were measured (see 'Temperature data,' below). Sampling conditions were occasionally poor, particularly towards the end of the period, due to high discharge or bad weather. Nevertheless, used with care, the registered mortality can indicate the seasonal pattern of mortality. Live juveniles (mainly $0+$ salmon) were also collected by electrofishing at 3 locations (lower, middle and upper sections) in the river on 6 September 2006. The fish were killed by an overdose of anaesthetics and preserved in ethanol or fixed in formaldehyde.

Quantitative electrofishing. As part of a surveillance program to elucidate the effects of the hydroelectric power developments on the salmonid populations in the watercourse, densities of juveniles were estimated by electrofishing in the River Ålva on 25 and 26 August 2005, and 2 and 4 October 2006. In 2005, 37 sites were surveyed, and in 2006, 13 of these sites were re-sampled. The sites were fished with either 3-, 2- or 1 -pass electrofishing. The combined catch data from sites with 2-pass fishing (9 sites each year) were used to estimate a mean catchability, $p$, for $0+$ fry (Bohlin et al. 1989). The catchability of fry was estimated at 0.40 and 0.49 in 2005 and 2006, respectively. The catches of parr $(1+, 2+, 3+)$ in the River Åelva were too low (particularly in 2005) to obtain a reliable estimate of catchability of these size groups, and the data were combined with similar data from the River Åbjøra (9 sites in 2005) to obtain a common estimate for catchability at 0.66 for both years. Salmon abundance $(N)$ was then estimated at each site(s) as:

$$
N_{\mathrm{S}}=T_{\mathrm{S}} \times\left[1-(1-p)^{k}\right]^{-1}
$$

where $T$ is the total catch at a site, and $k$ is the number of electrofishing passes at a site. Finally, salmon abundances were converted to densities and expressed as number of individuals per $100 \mathrm{~m}^{2}$.

Temperature data. Water temperature was monitored every hour by an automatic logger in the lower part of the river (Fig. 1) during July and August of 2005 and 2006. From 2004, 50 daily temperature measurements taken between 27 July and 8 October were provided (E. Sylten pers. comm.). Daily temperature measurements (each morning) were also available for
1974, 1976 and 1977, before regulation of the river, and from a location close to the present logging station (Fig. 1). Air temperatures were available from a nearby meteorological station.

Autopsy. A limited autopsy using a stereo microscope was carried out on a few fish that had been frozen or preserved in ethanol.

Histology. Following fixation in $4 \%$ formaldehyde, salmon fry were embedded in paraffin and longitudinally sectioned. Sections of $5 \mu \mathrm{m}$ thickness were stained with haematoxylin and eosine (H\&E) by routine methods (Bancroft \& Gamble 2002) and observed by light microscopy.

DNA extraction, PCR and sequencing. Eight frozen 0+ salmon, sampled on 6 September 2006, were thawed and slit open. Kidney samples (approximately $25 \mathrm{mg}$ ) from all fish were individually subjected to DNA extraction, performed according to the QIAamp DNA Mini Kit (Qiagen) tissue protocol. DNA was eluted in $200 \mu \mathrm{l}$ of elution buffer (EB). The general myxozoan primers Myxgen 1f and Myxgen 2r (Kent et al. 2000) were used to amplify parts of the SSU rDNA gene.

The $50 \mu \mathrm{l}$ PCR reaction mix contained $5 \mu \mathrm{l}$ of template DNA, $500 \mu \mathrm{M}$ of each primer, $200 \mu \mathrm{M}$ of each $\mathrm{dNTP}, 50 \mathrm{mM} \mathrm{KCl}, 1.5 \mathrm{mM} \mathrm{MgCl}, 10 \mathrm{mM}$ Tris- $\mathrm{HCl}$ ( $\mathrm{pH} 9$ at room temperature) and 2.5 units of Taq DNA polymerase (GE Healthcare). The following thermal parameters were used to amplify the SSU rDNA fragments: initial denaturation at $95^{\circ} \mathrm{C}$ for $5 \mathrm{~min}$, thereafter, 35 cycles of denaturation at $95^{\circ} \mathrm{C}$ for $45 \mathrm{~s}$, annealing at $54^{\circ} \mathrm{C}$ for $45 \mathrm{~s}$ and extension at $72^{\circ} \mathrm{C}$ for $45 \mathrm{~s}$. After 35 cycles an extension step at $72^{\circ} \mathrm{C}$ for 4 min was included to ensure complete elongation of all products. All PCR products were purified using the Qiaquick PCR purification kit (Qiagen) and sequenced in both directions using the DYEnamic ET dye terminators (GE Healthcare). Sequencing products were purified using the Dye Terminator removal kit (ABgene) and analysed on a MegaBACE ${ }^{1000}$ analysis system (GE Healthcare). To identify the obtained sequence, we used the Basic Alignment Search Tool (BLAST), at the website of the National Center of Bioinformatics (NCBI) www.ncbi.nlm.nih.gov/BLAST/.

\section{RESULTS}

\section{Juvenile densities}

In 2005, the average density of Atlantic salmon fry $(0+)$ at the electrofishing sites in the River Åelva was estimated to be 71 ind. $100 \mathrm{~m}^{-2}$ (Table 1). The density of parr $(1+, 2+$ and $3+)$ that year was very low, with an average (over 37 sites) of 3.3 ind. $100 \mathrm{~m}^{-2}$. In 2006, the 
Table 1. Salmo salar L. Average density of fry and parr in the River Åelva 2005 and 2006. For 2005, densities are given both for all 37 sites surveyed and those 13 sites that were surveyed in both years

\begin{tabular}{|c|c|c|c|c|c|c|c|}
\hline \multirow[t]{2}{*}{ Year } & \multirow[t]{2}{*}{ Sites } & \multicolumn{3}{|c|}{- Fry $(0+)$} & \multicolumn{3}{|c|}{$-\operatorname{Parr}(1+, 2+, 3+)-$} \\
\hline & & Mean & $\mathrm{SD}$ & Range & Mean & SD & Range \\
\hline 2005 & 37 & 71 & 53 & $3-211$ & 3.3 & 4.4 & $0-22$ \\
\hline 2005 & 13 & 102 & 62 & $18-211$ & 3.7 & 6.1 & $0-22$ \\
\hline 2006 & 13 & 13 & 12 & $0-40$ & 9.7 & 9.7 & $0-26$ \\
\hline
\end{tabular}

density of fry was significantly lower (comparison of 13 sites; Mann-Whitney $U$-test, $\mathrm{p}<0,001$ ) than in 2005, with an average of 13 ind. $100 \mathrm{~m}^{-2}$. The densities of parr in 2006 were higher than in 2005, with an average of 9.7 ind. $100 \mathrm{~m}^{-2}$. In 2005, 1+ salmon constituted $55 \%$ of the parr, whereas the contribution of this age-group to the parr population increased to $78 \%$ in 2006.

\section{Temperature}

River temperatures before regulation (1974, 1976 and 1977) were much lower than the temperatures measured in 2005 and 2006 (Fig. 2). The correlation between air and river temperatures during summer (from 1 July through 31 August) for the 3 yr before regulation was poor (Pearson correlation: $r=0.35$ ). After regulation, (data from 2005 and 2006) the correlations between air and river temperature was much higher $(\mathrm{r}=$ 0.70). Except for a short peak of high temperatures in mid-July, water temperatures were generally lower in the summer of 2005 than in 2006 (on average 15.4 and $17.5^{\circ} \mathrm{C}$, respectively). In 2006 there were $9 \mathrm{~d}$ with temperatures above $20^{\circ} \mathrm{C}$ and $24 \mathrm{~d}$ above $18^{\circ} \mathrm{C}$, whereas the corresponding numbers were 1 and $5 \mathrm{~d}$ in 2005 .

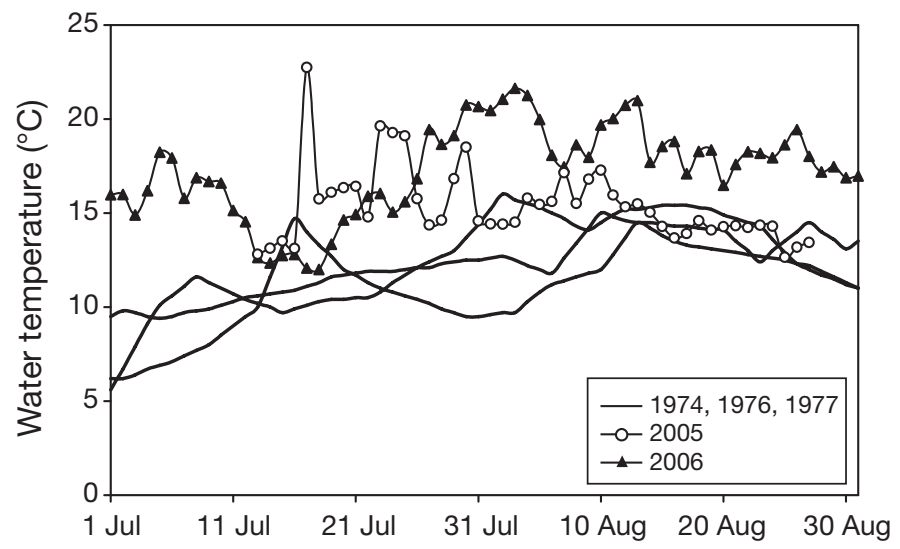

Fig. 2. Daily summer temperatures (1 July to 31 August) in the lower part of the River Åelva (Locations 1 and 2 in Fig. 1) during 3 years before regulation $(1974,1976,1977)$ and in 2005 and 2006
Although the temperature registrations for 2004 are somewhat fragmmentary (Fig. 3), temperatures were generally higher than in 2005, particularly in early August (above $20^{\circ} \mathrm{C}$ ). We have no systematic registration of water temperatures in 2002 and 2003, but air temperatures from a nearby meteorological station indicate that these summers were also warmer than the summer of 2005.

\section{Observation of mortality}

The pattern of mortality was similar among years (E. Sylten pers. comm.). In 2004, the first dead fish were found in late July, the numbers peaked in early September and few dead fish were found after 1 October (Fig. 3). All dead fish sampled were salmon fry, but mortality of older parr and trout cannot be ruled out because substrate composition (T. Forseth and $\mathrm{O}$. Ugedal unpubl. data) indicates that this part of the river is not particularly suitable for older fish.

\section{Autopsy}

Kidneys from 6 of 8 fish intended for PCR analyses were found to be pale and grossly distended, particularly the caudal portion. In fish preserved in ethanol, digenean metacercariae were commonly found in the pericardial and abdominal cavities, loosely attached to the viscera by connective tissue. However, the effect of these metacercaria to the fish or the correlation between the occurrence of flukes and the severity of

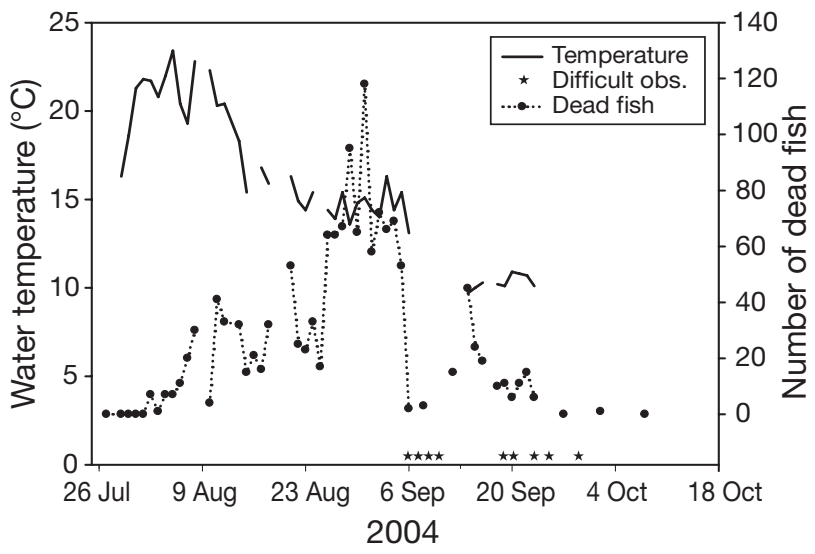

Fig. 3. Salmo salar L. Number of dead fish sampled each day and daily temperatures (late afternoon) in a $500 \mathrm{~m}^{2}$ area in the lower part of the River Åelva (Location 2 in Fig. 1) during summer in 2004. ( $\star$ ) Days with difficult observation conditions (high water discharge or bad weather) 
PKD has not yet been studied. Gross observations revealed extensive melanisation of the parietal wall of the pericardium, synechia between the apex of the heart ventricle and the pericardial wall, and adhesions between the pyloric caeca and the ventral peritoneal surface.

\section{Histological examination}

Longitudinal sections of fifteen $0+$ Atlantic salmon revealed that most fish had been eating actively and the ventricle was filled with more or less degraded exoskeleton components from insects and crustaceans. The kidney, particularly the caudal portion, was markedly swollen/ enlarged and protruded ventrally towards the abdominal cavity (Fig. 4). Kidney enlargement was the result of multifocal to diffuse oedema and interstitial granulomatous inflammation dominated by

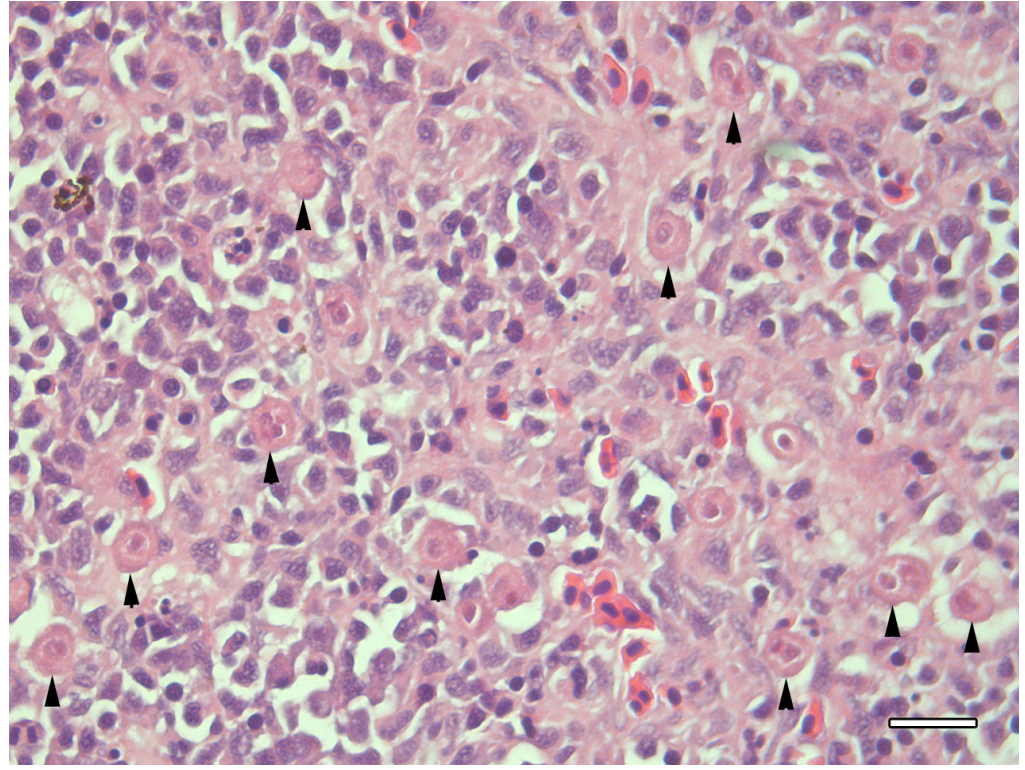

Fig. 5. Salmo salar L. Section of kidney stained with haematoxylin and eosine and colour modified in Adobe Photoshop. Numerous PKX cells ( $\longrightarrow$ ) can be seen throughout the degenerated tissue. Scale bar $=20 \mu \mathrm{m}$ macrophage- and lymphocyte-like cells.

Destruction of parenchymatic tissue was extensive and there was sclerosis of individual tubules. Characteristic eosinophilic to pale orange (often multinucleated) PKX cells surrounded by macrophages were found scattered throughout the lesions (Fig. 5). These aggregates were typically surrounded by a clear halo. Multifocal granulomatous inflammation with variable amounts of PKX cells was also found in the liver and spleen. Hepatic lesions frequently included multinucleated giant cells scattered throughout the lesions. Transverse and oblique sections of several metazoan parasites, presumably Diplostomum sp. or Tylodelphys sp., were found in the vitreous body caudally to the lens. Other trematode metacercariae were found in varying num- bers at different locations in the abdominal cavity, and in some cases also in the pericardial cavity. Two fish had fibrinous adhesions (synechia) between the apex of the ventricle and the parietal pericardium. One fish had several well-defined, rounded bodies (each with a hyaline capsule) scattered throughout the abdominal cavity. There was a marked chronic inflammatory response with melanisation around those structures.

In parr, granulomatous kidney lesions were of a more chronic character with widespread fibrosis. PKX cells surrounded by macrophages were widespread and numerous. Multifocal granulomatous inflammation was present in several other organs, including spleen, liver, pseudobranch and pancreas. In the pancreas, acinar

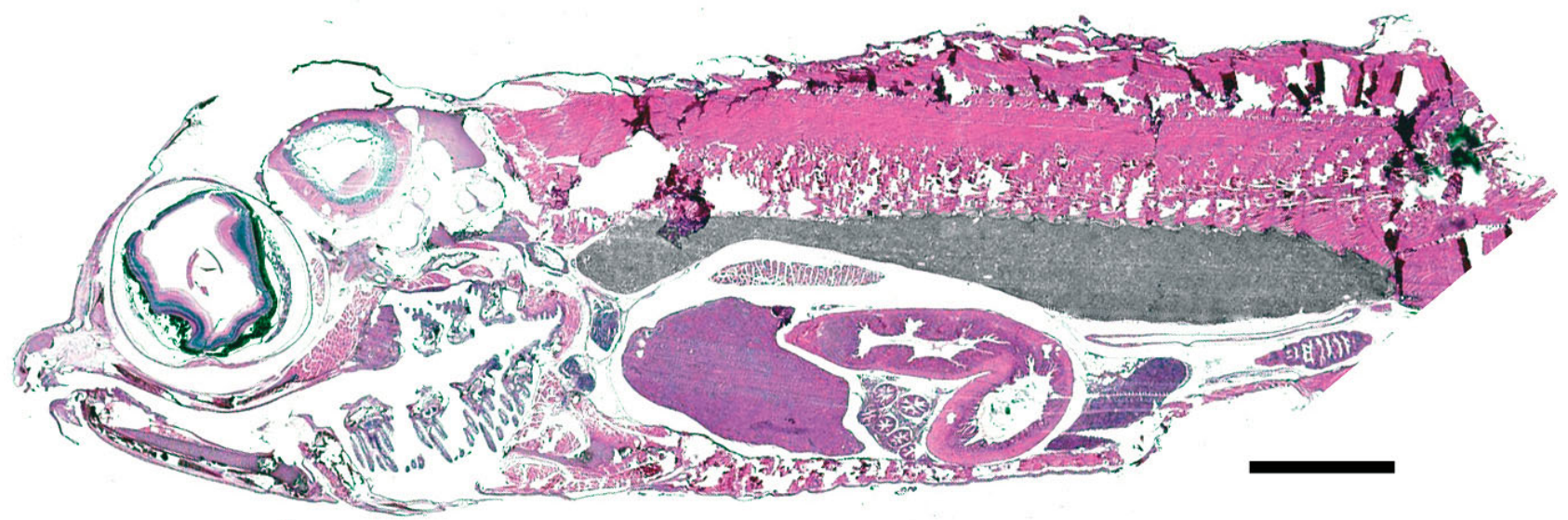

Fig. 4. Salmo salar L. Longitudinal section of a $0+$ fry, stained with haematoxylin and eosine and colour modified in Adobe Photoshop. Note that the kidney (gray) is swollen, especially in the posterior section. Scale bar $=2 \mathrm{~mm}$ 
tissue was more or less absent and had been replaced by granulomatous tissue. Strands of fibrinous tissue attached the pancreatic tissue to the ventral abdominal wall. Abdominal flukes were found in only 1 fish.

\section{Molecular diagnosis}

From the same 6 out of 8 fish which had pale and grossly distended kidneys at autopsy, a PCR product consisting of approximately 750 nucleotides (nt) was obtained. From 4 of these PCR products we were able to sequence $674 \mathrm{nt}$. No sequence variation was observed between the samples. The 674 nt sequence differed only in 2 nucleotide positions when compared to the SSU rDNA sequence (GenBank acc. no. U70623) from Tetracapsuloides bryosalmonae.

\section{DISCUSSION}

Mortality of Atlantic salmon fry in River Åelva was noted and non-systematic registration of dead fish was performed by a local landowner in the years 2002 to 2006. Dead juveniles (mainly fry) were found in 2002 to 2004 and in 2006, but not in 2005. Quantitative electrofishing at 37 locations in 2005 revealed high fry densities but very low parr densities. The latter indicates that the mortality of fry reported from 2002 to 2004 had been considerable. No fry mortality was observed in 2005 and the higher densities of 1+ parr in 2006 indicate that the survival of fry in 2005 was higher than in previous years. Official catch statistics of adult salmon do not indicate any major differences in recruitment from 2002 to 2004, leaving fry mortality from 2002 to 2004 as a likely explanation for the low density of parr in the river.

We have no data to directly assess the magnitude of the mortality, but crude estimates can be made. If we conservatively assume average fry densities to be 50 ind. $100 \mathrm{~m}^{-2}$ each year from 2002 to 2004 (observed average in the apparently 'normal' year 2005 was 71), and annual natural mortalities at $70 \%$ (also a conservative estimate), the expected densities of juveniles in 2005 (1+ from 2004, 2+ from 2003 and 3+ from 2002) would be approximately 20 ind. $100 \mathrm{~m}^{-2}$. The observed average density was 3.3 ind. $100 \mathrm{~m}^{-2}$, indicating an $85 \%$ reduction in parr densities due to PKD. Furthermore, if we assume that recruitment was similar in 2005 and 2006, adjust for differences in sampling dates (late August in 2005 and early October in 2006) by adding $15 \%$ mortality in 2005, autumn fry densities were $85 \%$ lower in 2006 than in 2005. According to official catch statistics, the catch of multi-sea-winter salmon (contributing the most to egg deposition due to female dominance and high egg numbers) was about the same in 2004 (116 ind.), and 2005 (128 ind.), indicating that recruitment was not very different. These estimates indicate that the smolt production in the river has been severely reduced.

Histological examination revealed that there was an extensive destruction of parenchymatic kidney tissue and sclerosis of individual tubuli. We also found multifocal granulomatous inflammation in the liver and spleen. Varying amounts of PKX cells could be seen, and the genetic identification of Tetracapsuloides bryosalmonae in affected tissue demonstrates the connection between the parasite and the observed pathological changes. Although other parasites were found and additional hypotheses for the observed mortality cannot be excluded, there is little doubt that $T$. bryosalmonae has significantly contributed to the observed pathology and mortality. Immunity of 1+, infected and survived as $0+$, has been reported (Clifton-Hadley et al. 1984). The fact that fry dominated among reported dead fish supports the conclusion that $T$. bryosalmonae was the primary cause of mortality in 2006.

The relationship between PKD and increasing/high water temperatures is well established (Clifton-Hadley et al. 1984, Gay et al. 2001, Longshaw et al. 2002, Tops et al. 2006). Water temperature affects several factors which all determine the probability for, or the outcome of, an infection. First, the occurrence and growth of bryozoans may be affected by temperature (Tops et al. 2006). Temperature also affects the onset, speed, and longevity of spore proliferation in bryozoans (Tops et al. 2006). Finally, temperature also affects immune responses in fish. Unspecific responses play a dominant role at lower temperatures, while specific responses are more pronounced at higher temperatures (Le Morvan et al. 1998). Growth and proliferation of Tetracapsuloides bryosalmonae within their bryozoan hosts, and infection of fish may occur at temperatures down to $8^{\circ} \mathrm{C}$ (Gay et al. 2001). However, $15^{\circ} \mathrm{C}$ is regarded as the lower limit for clinical outbreak of PKD. The high water temperatures in the summer of 2006 may well explain the outbreak of PKD in Åelva. The seasonal pattern of reported mortality (from late July through September) supports this view. It is reasonable to assume that the mortality observed from 2002 to 2004 also was caused by PKD triggered by high water temperatures, and that T. bryosalmonae-induced PKD is the cause for the observed decline in the salmon population. The relatively high densities of $0+$ in 2005 and the higher $1+$ densities in 2006 indicate that the PKD situation was better in 2005. Moreover, no dead fish were found by the local landowner in 2005. This can likely be attributed to the cooler temperatures in the summer of 2005 than in the other years between 2002 and 2006). 
Although temperatures above $15^{\circ} \mathrm{C}$ seem essential for outbreaks of clinical PKD, infective spores may be present at considerably lower temperatures. At natural sites displaying water temperatures down to $8^{\circ} \mathrm{C}$, infectious malacospores were present throughout the year, and fish were simultaneously susceptible to infection (Gay et al. 2001). In infection trials performed at a range of temperatures down to $4.5^{\circ} \mathrm{C}, 7$ to $8^{\circ} \mathrm{C}$ was regarded as a minimum temperature for development of infective spores. It is therefore important to consider the duration of periods with water temperatures above this limit for spore development. In Norwegian salmon rivers, where the temperatures in general are quite low, a prolonged period with water temperatures above this limit may have important consequences for the prevalence and intensity of Tetracapsuloides bryosalmonae in 0+ fry, and thus for subsequent disease outbreaks when the temperature rises above $15^{\circ} \mathrm{C}$ in the summer.

The occurrence of Tetracapsuloides bryosalmonae in Norwegian waters has never been studied and there is no clear explanation for its presence in the Åbjøra watercourse. Molecular evidence indicates that $T$. bryosalmonae was introduced to Europe from North America through transcontinental dispersal not linked to human-mediated activities (Henderson \& Okamura 2004). Most probably, both this transcontinental dispersal and subsequent dispersal within Europe is linked to waterfowl-mediated transport of bryozoan statoblasts (Henderson \& Okamura 2004). Despite long-lasting and widespread farming and distribution of the North American rainbow trout throughout Europe, there is no evidence for $T$. bryosalmonae being spread together with this host. However, as T. bryosalmonae spores can be transmitted from fish to the freshwater bryozoan Fredericella sultana and back to fish (Morris \& Adams 2006) we recommend that stocking of T. bryosalmonae infected fish should be avoided until the role of the fish host for the distribution and further spread of this parasite has been fully understood. Supportive stocking of brown trout in watercourses exploited for hydro-electric power is common in Norway and T. bryosalmonae have been diagnosed in a Norwegian fish farm producing brown trout for stocking (T. A. Mo and T. T. Poppe pers. obs.). Such stocking may have resulted in the spread of the parasite within Norway. Future studies will show the relationship between sequences of Norwegian isolates of $T$. bryosalmonae and also their relationship to known sequences from other European isolates.

Although information on the distribution of Tetracapsuloides bryosalmonae in Norway is lacking, knowledge of freshwater bryozoans in Norway is very good. Cristatella mucedo and Fredericella sultana, the most likely hosts for T. bryosalmonae in Norway, are common and were present in 191 and 67 of 473 investigated localities respectively (K. A. Økland \& J. Økland 2000, 2001). Both species are most common in water bodies with summer water temperatures between 11 and $20^{\circ} \mathrm{C}$, but at temperatures over $16^{\circ} \mathrm{C}$ the occurrence of $C$. mucedo showed a significantly higher frequency than expected on a basis of random distribution (K. A. Økland \& J. Økland 2000). This implies that this species will most probably become more abundant in areas experiencing elevated water temperatures. In addition, it is likely that higher temperatures will also support a higher growth rate of $C$. mucedo and F. sultana, which in turn will increase the number of potential hosts for $T$. bryosalmonae in watersheds where these bryozoans are already present.

Tops et al. (2006) predicted an increase in the magnitude and severity of PKD outbreaks as a direct result of climate-driven enhanced proliferation of bryozoan hosts. The water temperatures in the River Ålva have increased in recent years, and we suggest that the observed PKD outbreak can be linked to this increase. However, it looks as though this is not primarily an effect of climate change. Hydropower regulation of the river, with a $25 \%$ diversion of water from the catchment, is the probable main source for the elevated temperatures. After regulation, the river's summer temperatures are to a large degree determined by solar influx (air and water temperature correlation: $r=0.70$ ). Before regulation, the correlation between air and water temperatures was poor $(r=0.35)$, and summer temperatures were lower due to higher water discharges and snowmelts at high altitudes. The present study emphasizes the need to consider the potential consequences for salmonid populations of elevated temperatures caused by hydropower developments. Our results also stress the importance of considering the roles of infective organisms when natural salmon populations are declining.

Following the discovery of Tetracapsuloides bryosalmonae-induced PKD in River Åelva, the parasite and the disease were discovered in the River Jølstra in Western Norway, another river where salmonid decline has been seen. These alarming findings prompted a closer examination of fish from other salmon rivers in Norway. Kidney samples of $0+$ salmon from 18 Norwegian rivers were subjected to PCR and sequencing to check for the presence of $T$. bryosalmonae. In some of these rivers the salmon populations have been severely reduced. The results from the screening showed that $T$. bryosalmonae is present in most of these rivers. However, it is too early to conclude that PKD is involved in the decline in the salmon population in any of the rivers. The present study, showing the severe population effects of PKD in a reg- 
ulated river with elevated summer temperatures, may serve as an early warning on the potential future effects of warmer climate on the northern salmonid fishes.

Acknowledgements. Field sampling and analyses of population data were financed by the Nord-Trøndelag Hydro-power Company and Åbjøra Power. We thank E. Sylten for sampling and registration of dead fish, and J.G. Jensås, L. Saksgård and R. Saksgård for technical assistance. The Norwegian Veterinary Institute and Norwegian Institute for Nature Research also provided financial support.

\section{LITERATURE CITED}

Bancroft JD, Gamble M (2002) Theory and practice of histological techniques, 5th edn. Churchill Livingstone, London

Bohlin T, Hamrin S, Heggberget TG, Rassmussen G, Saltveit SJ (1989) Electrofishing - theory and practice with special emphasis on salmonids. Hydrobiologia 173:9-43.

Canning EU, Curry A, Feist SW, Longshaw M, Okamura B (1999) Tetracapsula bryosalmonae n. sp. for PKX organism, the cause of PKD in salmonid fish. Bull Eur Assoc Fish Pathol 19:203-206

Canning EU, Curry A, Feist SW, Longshaw M, Okamura B (2000) A new class and order of Myxozoans to accommodate parasites of bryozoans with ultrastructural observations on Tetracapsula bryosalmonae (PKX organism). J Eukaryot Microbiol 47:456-468

Canning EU, Tops S, Curry A, Woods TS, Okamura B (2002) Ecology, development and pathogenicity of Buddenbrockia plumatellae Schröder, 1910 (Myxozoa, malacosporea) (syn. Tetracapsula bryozoides) and establishment of Tetracapsuloides $\mathrm{n}$. gen. for Tetracapsula bryosalmonae. J Eukaryot Microbiol 49:280-295

Clifton-Hadley RS, Bucke D, Richards RH (1984) Proliferative kidney disease of salmonid fish: a review. J Fish Dis 7: 363-377

Feist SW, Peeler EJ, Gardiner R, Smith, E, Longshaw M (2002) Proliferative kidney disease and renal myxosporidosis in juvenile salmonids from rivers in England and Wales. J Fish Dis 25:451-458

Editorial responsibility: Dieter Steinhagen,

Hannover, Germany
Gay M, Okamura B, de Kinkelin P (2001) Evidence that infectious stages of Tetracapsula bryosalmonae for rainbow trout Oncorhynchus mykiss are present throughout the year. Dis Aquat Org 48:31-40

Henderson M, Okamura B (2004) The phylogeography of salmonid proliferative kidney disease in Europe and North America. Proc R Soc B 271:1729-1736

Kent ML, Khattra J, Hedrick RP, Devlin RH (2000) Tetracapsula renicola $\mathrm{n}$. sp. (Myxozoa: Saccosporidae); the PKX myxozoan - the cause of proliferative kidney disease of salmonid fishes. J Parasitol 86:103-111

Le Morvan C, Troutaud D, Deschaux P (1998) Differential effects of temperature on specific and nonspecific immune defences in fish. J Exp Biol 201(2):165-168

Longshaw M, Le Deuff RM, Harris AF, Feist SW (2002) Development of proliferative kidney disease in rainbow trout, Oncorhynchus mykiss (Walbaum), following shortterm exposure to Tetracapsula bryosalmonae infected bryozoans. J Fish Dis 25:443-449

Morris DJ, Adams A (2006) Transmission of Tetracapsuloides bryosalmonae (Myxozoa: Malacosporea), the causative organism of salmonid proliferative kidney disease, to the freshwater bryozoan Fredericella sultana. Parasitology 133:701-709

Morris DJ, Ferguson HW, Adams A (2005) Severe, chronic proliferative kidney disease (PKD) induced in rainbow trout Oncorhynchus mykiss held at a constant $18^{\circ} \mathrm{C}$. Dis Aquat Org 66:221-226

Økland J, Økland KA (2005) Freshwater bryozoans (Bryozoa) of Norway V: review and comparative discussion of the distribution and ecology of the 10 species recorded. Hydrobiologia 534:31-55

Økland KA, Økland J (2000) Freshwater bryozoans (Bryozoa) of Norway: Distribution and ecology of Cristatella mucedo and Palucidella articulata. Hydrobiologia 421:1-24

Økland KA, Økland J (2001) Freshwater bryozoans (Bryozoa) of Norway II: distribution and ecology of two species of Fredericella. Hydrobiologia 459:103-123

Tops S, Lockwood W, Okamura B (2006) Temperature-driven proliferation of Tetracapsuloides bryosalmonae in bryozoan hosts portend salmonid decline. Dis Aquat Org 70:227-236

Wahli T, Knuesel R, Bernet D, Segner H, Pugovkin D, Burkhardt-Holm P, Escher M, Schmidt-Posthaus H (2002) Proliferative kidney disease in Switzerland: current state of knowledge. J Fish Dis 25:491-500

Submitted: March 23, 2007; Accepted: July 6, 2007 Proofs received from author(s): September 17, 2007 